\title{
Using Online Social Networks to Acquire Political Information: the Politically Engaged Non-ideological Youth in Chile, 2017-2019
}

\section{Gonzalo Espinoza Bianchini $^{1}$ (D) Patricio Navia ${ }^{2,3}$ (D) Camilla Ulriksen Lira ${ }^{2}$ (D)}

Accepted: 2 June 2021/ Published online: 18 June 2021

(C) The Author(s), under exclusive licence to Springer Science+Business Media, LLC, part of Springer Nature 2021

\begin{abstract}
This paper assesses the impact of age and ideological identification on the left-right scale on the use of online social networks to acquire political information. Sociodemographic indicators and ideological identification have been found to impact democratic engagement and the access and use of social networks. In countries where the digital divide (access to the internet) and digital inequality (use of the internet) coexist, the impact of socio-demographic indicators is stronger, as those with fewer tools and resources have less access and make less use of social networks for democratic engagement. We postulate three hypotheses on the effect of socio-demographic determinants and ideological identification and test them using 6 national polls conducted between 2017 and 2019 in Chile, a middle-income country with high levels of inequality. Though socio-demographic variables and ideological identification impact the use of social networks to acquire political information, young people who do not identify on the ideological scale are as likely to use social networks to obtain political information as older people who identify on the left-right scale. As generational replacement kicks in, online democratic engagement will become more intense. Even the non-ideological youth is more politically engaged than the ideologically identified older age cohorts.
\end{abstract}

Patricio Navia

patricio.navia@nyu.edu

Gonzalo Espinoza Bianchini gespinozabianchini@gmail.com

Camilla Ulriksen Lira camiulriksen@gmail.com

1 Political Electoral Observatory, Universidad Diego Portales, Santiago, Chile

2 School of Political Science, Universidad Diego Portales, Santiago, Chile

3 Liberal Studies, New York University, New York City, NY, USA 
Keywords Social network use $\cdot$ Political information consumption · Ideological identification $\cdot$ Age cohorts $\cdot$ Socioeconomic differences

This paper analyzes the differentiated impact of ideological identification on the use of social networks to obtain political information by different age cohorts. It is nonsurprising that the use of digital technologies is lower among older age cohorts, but the use of digital technologies to acquire political information might also be different among people who differ in their ideological identification. Those who identify on the left-right scale — and who are also more likely to be interested in politics - are expected to make use of social networks to acquire political information more so than those who do not identify on the left-right scale. The combination of the negative impact of age and a positive impact of ideological identification on using social networks to acquire political information should result in that the younger non-ideologically identified age cohorts and the older ideologically identified age cohorts will be less likely to make use of social networks to acquire political information.

In addition, access to the internet should also impact the ability of people to make use of social networks to acquire political information. In industrialized countries, where there is quasi universal access to the internet, the digital divide has narrowed, but differences in the use of social networks (digital inequality) remain-especially when acquiring political information. In middle and low-income countries with high levels of income and social inequality, socio-economic determinants continue to explain access to the internet and the use of social networks. In countries where entry barriers explain the digital divide and digital inequality, the impact of the use of social networks on the democratic process presents a more complex picture, but it potentially also offers an opportunity to level the playing field and reduce the democratic engagement gap that results from income and economic inequality.

Our case study is Chile, a middle-income country with high levels of social and income inequality. In 2017, Chile ranked 58 among 185 countries in GDP per capita according to the International Monetary Fund and was the most developed country in Latin America. Yet, as many neighbors, Chile has high levels of income inequality. According to the World Bank Development Indicators, Chile ranks 132 among 166 countries in the world in income inequality, with a Gini coefficient of 0.44 in 2017. Chile also ranks high in other dimensions of inequality, like unequal access to education, health and pensions. Multiple dimensions of inequality have become salient electoral and political issues in recent years. The expansion and use of the internet reflect Chile's complex picture of rapid economic development with persistently high levels of inequality. While $72.7 \%$ of higher income Chileans aged 61 and older have internet access, the figure for those in the same age group but in the lowest income bracket is only $15.1 \%$. Among those aged 29 or younger, internet access reaches $85.4 \%$ in the highest income group and $58.7 \%$ in the lowest income group (PNUD, 2017a). Though differences in access to the internet are present across all age groups, those differences are lower among the younger population. After all, while material inequality — the access to the internet—might be high, the actual use 
of the material resources-concrete inequality-is lower as the gap in use across socio-economic groups is much lower among the younger population.

In what follows, we discuss the determinants of the use of social networks to acquire political information and postulate 3 hypotheses on the impact of socioeconomic status, age, and identification on the ideological scale on acquiring political information through social networks. We then introduce the case of Chile and discuss our methodology. After presenting the inferential analysis, we discuss our results that show how young Chileans who do not identify on the ideological scale use the internet to acquire political information more than the politically identified older population. We finish by examining the implications of our findings beyond the case of Chile.

\section{Digital Inequality and the Digital Divide}

Digital technologies offer new opportunities to promote economic development, social inclusion, educational access, democratic engagement, and good governance (Hsieh et al., 2008). However, digital technologies also bring negative externalities. When countries develop, the digital divide decreases, but digital inequality does not automatically decline, as it depends on income differences and other forms of social inequality (Chen \& Wellman, 2004, 2005). Digital inequality responds to the tools people have to make use of whatever access they have to the internet (Acilar, 2011). In developing countries, the expansion of the internet has reproduced prior levels of social and income inequality (Chang Ho \& Tseng, 2006). Comparing countries with similar levels of development, digital inequality increases wherever there is income inequality (Fuchs, 2009, Fuch \& Horak, 2008). Technology might end up widening social gaps and creating an educational and economic divide between those with and without access and between those with and without the abilities to use digital technologies (Di Maggio \& Hargittai, 2001).

Those with higher levels of education tend to have more skills and greater autonomy when using digital technologies and give the internet a more diverse use (Hargittai \& Hinnant, 2008). Those with fewer skills and education might fail to find relevant information and useful tools on the internet and, consequently, might end up using it less (Ono \& Zavodny, 2007; Van Deursen et al., 2017). Younger people are also more likely to take advantage of the internet than older people with similar levels of education (Ono \& Zavodny, 2007). Though, in recent years, the generational gap in the access and use of online news has decreased substantially (Taneja et al., 2018)_ just as the gap in access between younger and older users decreases as accessibility to the internet becomes more widespread (Taneja \& Viswanathan, 2014).

Still, even when it is universal, access to digital technologies might widen the knowledge gap (Hargittai \& Hinnant, 2008; Hsieh et al., 2008), as some people use the internet for their advancement and others fail to use it for beneficial purposes (Norris, 2000). In industrialized countries, there is a growing focus on digital inequality - the tools that allow people with access to digital technologies to take advantage of the opportunities provided by such access (Di Maggio \& 
Hargittai, 2001; Hargittai \& Hinnant, 2008; Van Deursen et al., 2017). There is a well-grounded concern that digital inequality reflects and reproduces the social and economic inequalities that already exist in society (Ono \& Zavodny, 2007). In fact, the growth of digital technologies can exacerbate the gap in what Tilly (2001) calls material and concrete inequalities - the access to resources and the use of those resources, respectively.

Industrialized countries with low levels of income and social inequality also tend to have low levels of digital divide and digital inequality, while developed countries that have high levels of income inequality might present low levels of digital divide but high levels of digital inequality. In turn, in less developed countries with high levels of inequality, the use of the internet will reproduce the drastic differences between the haves and have-nots. As a middle-income country, Chile falls among the countries where access to the internet is rapidly expanding-but remains far from universal-and differences in the uses that people give to that access reflect the persistent levels of inequality in other dimensions of daily life. Though digital inequality impacts different dimensions of society, we here focus on its effect on one form of democratic engagement, the use of online social networks to acquire political information.

\section{The use of the Internet to Acquire Political Information}

Acquiring political information is a central aspect of democratic engagement. Political information is important as it helps shape the schemes people use to form attitudes and to act on political issues. Schemes are mental structures that help us organize the social information and that guide our cognitive process (Baron \& Byrne 1987: 84). These schemes are dependent on the information available that people pay attention to. People are more likely to pay attention to information that is consistent with previously established schemes and to ignore information that contradicts those schemes, unless that information is so extreme that it becomes impossible to ignore (Fiske 1993). The information is codified within the schemes associated to political views that people already possess and then the information is stored in one's memory. Since we pay more attention to information that confirms our beliefs, it is more likely that we will store that information in our longterm memory. Yet, unanticipated information captures our attention and forces its way into our long-term memory (Stangor \& McMillan 1992). Later, people retrieve this information from their schemes to generate attitudes, judgments, and behavior (Baron \& Bryne 1987).

As acquiring information plays a central role in the formation of attitudes, the way in which people engage in democracy responds, at least partially, to the information they obtain. Not surprisingly, the use of the internet has been found to have an impact on democratic engagement (Gil de Zúñiga et al., 2012) and on the way people express their political views (Yamamoto et al., 2015). Using the internet also increases interest in politics (Morris \& Morris, 2013), especially among young people, in both western and Asian countries (Chen et al., 2016). In addition, the impact is different depending on whether people use the internet for information, 
interaction, or creative production. In the case of information, the impact is indirect (Ekström \& Östman, 2015). Those with more interest in politics are more likely to use the internet for civic purposes and to acquire news and information, though the use of social networks varies by age and gender. For example, women are more active in posting political information online on Facebook (Glynn et al., 2012).

Inequality affects online democratic engagement (Anduiza et al., 2009; Min, 2010). Digital inequality impacts the online access to political information (Di Maggio \& Hargittai, 2001; Ono \& Zavodny, 2007). Those in higher socio-economic groupswho are also more likely to have higher levels of education- tend to have more interest in politics and to use the internet more to acquire information (Anduiza et al., 2014; Dalton, 2006; Wang, 2007). Higher income and educational levels also positively impact the probability of using the information obtained online to guide political decisions (Kaye \& Johnson, 2004; Gronlund, 2007). Consequently, we would expect that those who are relatively better off-in terms of income, education, and other indicators of socio-economic status-will have a higher probability of using online networks to acquire political information. Thus, our first hypothesis postulates that:

H1: The higher the socio-economic status, the more use of online social networks to acquire political information.

The modern citizen sees the internet as an essential channel to acquire political information (Gronlund, 2007). In fact, the internet seems to have a positive effect on people's interest in politics (Kaye \& Johnson, 2002, 2004). While older people use traditional media to acquire political information, younger people are more likely to use the internet and social networks to do so (Holt et al., 2013; Tewksbury et al., 2001; Weaver et al., 2011). Young people spend more time on the internet and, thus, are also more exposed to accessing political news (Tewksbury et al., 2001; Xenos $\&$ Moy, 2007). Younger people are also more likely to follow political campaigns on the internet (Anduiza et al., 2010) and use digital technologies as communication tools and entertainment devices, while older people first use it for work-related purposes and as a source of information (Antino et al., 2016; Hargittai \& Hinnant, 2008). Age affects the different ways in which people acquire political information (Holt et al., 2013; Kaye \& Johnson, 2004) and, since the differences in the use of internet also impact who obtains political information online, younger people end up using the internet more and using it more to acquire political information. Consequently, our second hypothesis associates age with the use of online social networks to acquire political information:

$\mathrm{H} 2$ : The lower the age, the more use of online social networks to acquire political information.

Studies on online engagement have shown that people who already have a high interest in politics are more likely to be engaged in political practices and on acquiring information on the internet (Kaye \& Johnson, 2002, Jouët et al., 2011). Other studies have also shown that those with strong ideological views tend to be more active online than the rest (Barberá et al., 2015) and that social media consumption induces higher off and online political activism (Leyva, 2017). Moreover, people who are more extremist tend to seek out in online interactions those who will reaffirm, rather than challenge, their views (Boutyline \& Willer, 2017). Extending that argument to the use of social networks to acquire political information, we would 
expect that people who have strong ideological views-regardless of where they place themselves on the left-right scale-will be more likely to use online social networks to acquire political information than those who do not place themselves on the left-right scale or those who have more moderate views in general. Thus, we propose a third hypothesis:

H3: Those who place themselves on the extremes of the left-right ideological scale are more likely to use online social networks to acquire political information.

Thus, our expectations are that younger people in higher socio-economic status groups who have extreme views on the left-right scale will be the most likely to use social networks to acquire political information. Yet, we have no prior on which dimension is more relevant. That is, we do not know if low-income young people who report no ideological identification will make more use of the internet to acquire political information than high-income older people who place themselves on the left-right ideological scale.

\section{The Case of Chile}

According to the IMF, Chile is a middle-income country (though the World Bank has begun classifying Chile among high-income countries). In 2018, Chile ranked among the top three countries in Latin America in terms of GDP per capita, regardless of whether it was calculated as a purchasing power parity indicator, in nominal or constant US dollars. Though it remains one of the poorest OECD countries-a group of the most developed countries in the world-Chile's GDP per capita has increased faster than any other Latin American country since 1990.

Yet, Chile remains a highly unequal country. Income inequality reflects the differences in access to opportunities, social services, and political rights between higher and lower-income Chileans. In the late 1990s, Chile had the highest inequality in Latin America (Ruiz Tagle, 1999; Hughes \& Mellado, 2016). In 2013, its Gini coefficient was 0.5 , much higher than the range of 0.25 to 0.35 in OECD countries (Beyer \& Le Foulon, 2002; Larrañaga \& Rodríguez, 2014). The most recent Gini coefficient, in 2017, was 0.44 , the lowest on record for Chile, but still higher than the average for OECD countries.

Though levels of inequality have decreased over time (Larrañaga \& Rodríguez, 2014), inequality remains a pending issue for Chile and combating it is a common campaign issue in elections and a priority in public opinion polls. The Ministry of Social Development produces a comprehensive biannual report on poverty and inequality that reflects the high priority that the government and society in general give to this issue. A 2017 report on inequality found that Chileans value equal opportunities as more important than economic handouts (PNUD, 2017b). Other indicators of inequality are also high. In 2010, the country had one of the lowest female participation ratios in the labor force in Latin America. In recent years, that figure has improved, but it remains lower than in countries at comparable levels of development (PNUD, 2017a). Inequality is observed beyond economic indicators, as it is present even in the way the television news agenda is construed (Valenzuela \& 
Arriagada, 2011). For that reason, as we discuss below in the methodology section, we use an indicator of socio-economic status (SES) — and not just income level—to capture the presence of inequality among Chileans.

Historically, access to the internet has been higher in urban areas and among the younger, more educated, and higher income groups (Maldifassi \& Canessa, 2009). Younger people have also made more use of the internet, including social networks, especially for political engagement (Quijada, 2014; Scherman et al., 2013), while older Chileans use social network sites more for hedonic motivations (RamírezCorrea et al, 2019). In recent years, access and use of the internet have substantially grown. According to the Under Secretary of Telecommunications (2018), in 2015, $70.2 \%$ of Chileans had access to the internet, while in 2017 that number reached $87.4 \%$.

Figure 1 shows access to the internet and use of digital social networks to acquire political information by age and socio-economic status (SES) groups, as reported in Center for Public Studies (CEP, in the Spanish acronym) 2017-2019 polls. In all SES groups, access and use is higher among younger people. There is a big gap in access between those of low SES group and everyone else. In fact, the middle SES group is closer to the high SES group than to the low SES group in access to the internet. Those SES differences in access are far less pronounced among younger age groups. The use of the internet also reflects SES differences-but, again, the medium SES group is closer to the high SES group than to the low SES group in their use of the internet. Internet use is also higher among younger people in all SES groups, but age differences in access are bigger among those in the low SES group. Younger people use the internet more, in all SES groups, but there
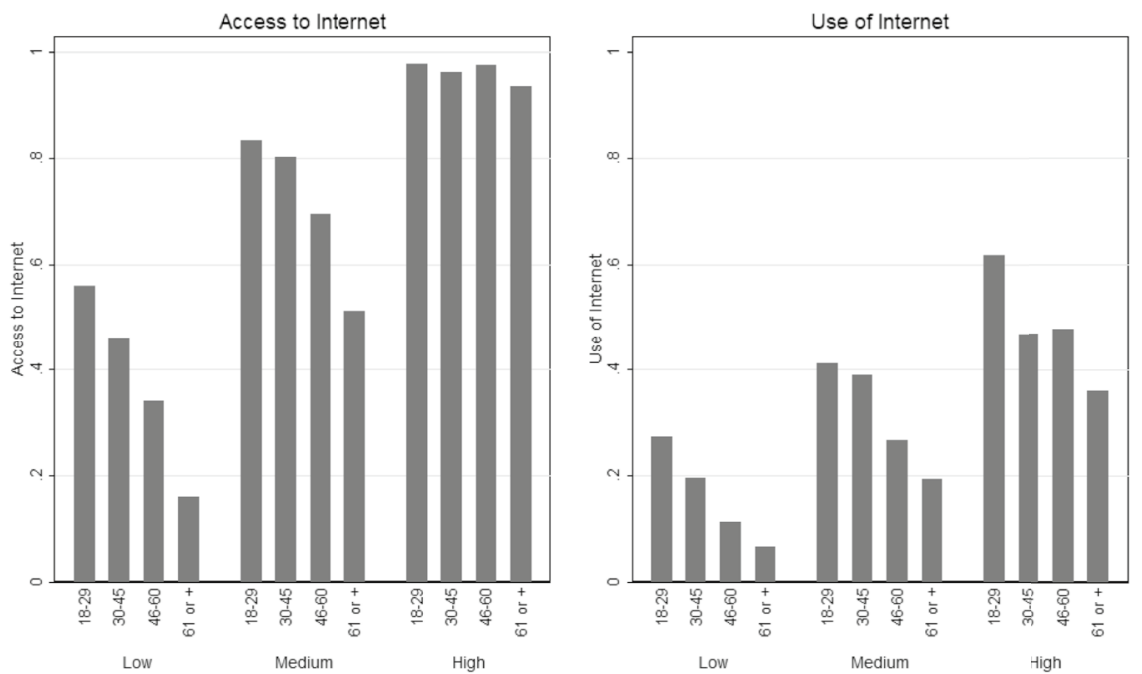

Socio-economic group

Fig. 1 Internet access and use of social networks to acquire political information by age and socioeconomic status, Chile, CEP polls, 2017-2019. Source: authors with data from CEP polls \#79, \#80, \#81, \#82, \#83, and \#84, 2017-2019 
are bigger differences in use among the oldest age category-with the lowest SES group using it far less than the comparable medium and high SES group in that age category. Logically, ideological identification has no impact on the access to internet or in the use of the internet.

\section{Methodology}

To test the 3 hypotheses, we use 6 polls from Centro de Estudios Públicos (CEP), a private public-interest think-tank in Chile. CEP polls, conducted regularly since the mid-1980s, have been widely used on studies on political identification and electoral preferences in Chile due to their rigorous methodology and public-access nature (Quiroga, 2008; Navia \& Perelló, 2019; Valenzuela et al., 2007).

The polls had a probabilistic sample that was representative of the national population aged 18 and older and were conducted in April/May 2017 (CEP79), July/August 2017 (CEP80), September/October 2017 (CEP81), October/November 2018 (CEP82), May 2019 (CEP83), and December 2019 (CEP84). Since 2017 was a presidential election year, CEP conducted three polls, while there was only one poll conducted in 2018 and two in 2019. The number of interviews in the six polls was 8602 persons. The data and methodology of the polls can be found at https://www.cepchile.cl/cep/site/edic/ base/port/encuestasCEP.html.

The dependent variable is the use of social networks to acquire political information. Though the primary use for the internet is recreational and for social networks use (Kubey et al., 2001, Stoycheff et al., 2020), we focus on those who use it for non-recreational purposes. The CEP poll includes a question on the frequency of use of social networks to obtain political information. Respondents have three options: frequently, sometimes, or never. As 75\% responded "never," we recoded that as "no" and the other two options (frequently or sometimes) as "yes".

The independent variables of interest for the three hypotheses are socioeconomic status (SES), age, and identification on the ideological scale. SES is coded in three values: high, medium, and low. SES is an indicator widely used in Chile, registered by the pollster and based on the reported income by the respondent, the educational level, the size of the family unit, the quality of the housing unit the respondent lives in, the income levels in the neighborhood, and other indicators associated to the material well-being of the respondent beyond the reported income levels or as proxies to estimate income levels for those respondents not reporting them (AIM, 2019).

Age is a continuous variable (18 to 93 years of age). Identification on the ideological scale is coded following the CEP polls that ask about it on a 6-point scale (left, center-left, center, center-right, right, and none). We follow most studies on Chilean politics - and since many people choose not to identify on the left-right scale-we recoded ideological identification into 4 categories: left, center, right, and none. Figure 2 shows the breakdown of ideological identification in Chile.

As additional control variables, we use education (a continuous variable from 0 to 20 years of education), gender (woman =1) and region of residency. In residency, we created a dummy variable to distinguish those in the Santiago Metropolitan 


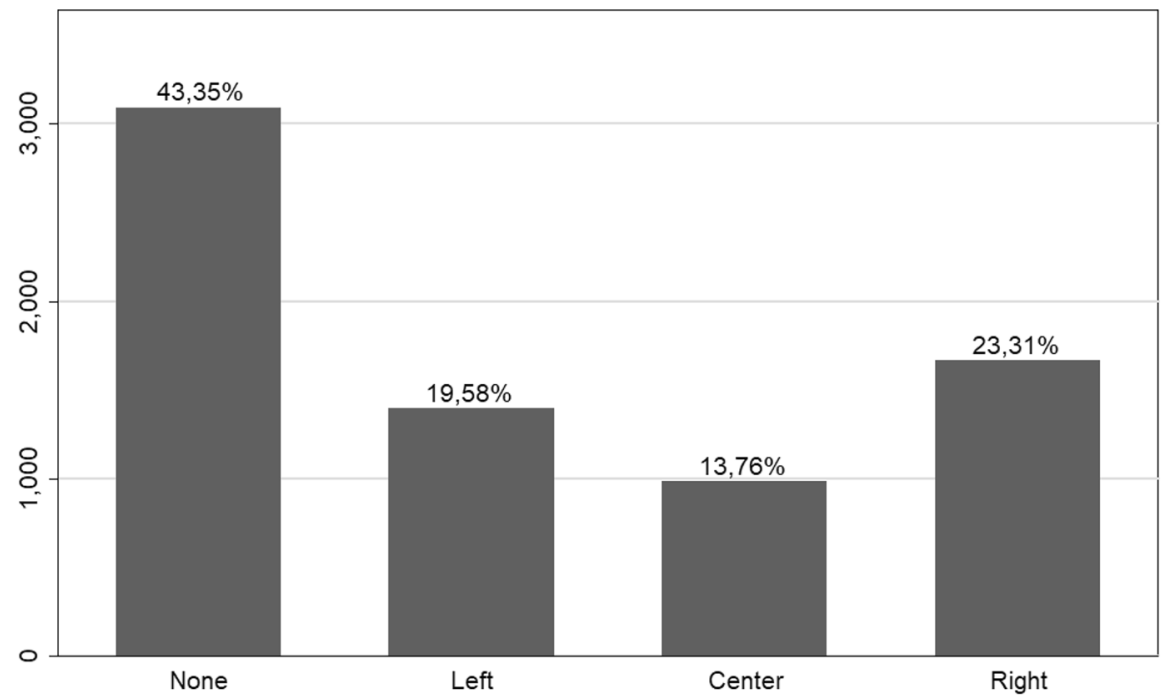

Fig. 2 Ideological identification in Chile, 2017-2019. Source: CEP Poll \#79, \#80, \#81, \#82, \#83, and \#84

Region (about $35 \%$ of the country) from the rest of Chile. Table 1 shows the descriptive statistics for the independent and dependent variables.

\section{Inferential Analysis}

To test our hypotheses on the impact of socio-economic status, age, and ideological identification on the use of social networks to acquire political information, we estimated binary logistic models using the CEP polls. Table 2 shows the models. First, we estimated Model 1 to account for the determinants of access to the internet. Younger people and those in higher SES groups are more likely to have access to the internet. Though the middle SES group has significantly more access to the internet than the lower SES group, the high SES group has substantially more

Table 1 Descriptive statistics of independent and dependent variables, CEP polls, 2017-2019

\begin{tabular}{lccclc}
\hline Variable & $\mathrm{N}$ & Media & SD & Min & Max \\
\hline Access to internet & 7315 & 0.57 & 0.494 & 0 & 1 \\
$\begin{array}{l}\text { Use of social networks to } \\
\quad \text { acquire political informa- }\end{array}$ & 7315 & 0.25 & 0.433 & 0 & 1 \\
$\quad$ tion & & & & & \\
Socioeconomic group & 7315 & 0.64 & 0.548 & 0 & 2 \\
Age (continuum) & 7315 & 30.9 & 17.67 & 0 & 75 \\
Region & 7315 & 0.37 & 0.486 & 0 & 1 \\
Gender (women) & 7315 & 0.614 & 0.486 & 0 & 1 \\
Years of education & 7315 & 11.10 & 4.166 & 0 & 20 \\
\hline
\end{tabular}

Source: CEP Poll \#79, \#80, \#81, \#82, \#83, and \#84 
Table 2 Binary logistic regressions on access to the internet and use of the internet to acquire political information in Chile, CEP Polls, 2017-2019

Model 1 Access to internet
Model 2 Use of internet to acquire political information
Model 3 Use of internet to acquire political information

\begin{tabular}{lccc}
\hline Socioeconomic group: & - & - & - \\
$\quad$ Low & & & \\
Medium & $1.128^{* *}(0.060)$ & $0.399^{* * *}(0.072)$ & $0.368^{* * *}(0.074)$ \\
High & $2.632^{* *}(0.336)$ & $0.424^{* * *}(0.179)$ & $0.359^{* *}(0.184)$ \\
Years of education & $0.221^{* *}(0.009)$ & $0.165^{* * *}(0.010)$ & $0.152^{* * *}(0.010)$ \\
Age & $-0.019^{* * *}(0.001)$ & $-0.013^{* * *}(0.001)$ & $-0.015^{* * *}(0.001)$ \\
Women & $0.033(0.058)$ & $-0.287^{* * *}(0.059)$ & $-0.236^{* * *}(0.061)$ \\
Metropolitan Region & $0.569^{* * *}(0.060)$ & $0.171^{* *}(0.060)$ & $0.214 * * *(0.062)$ \\
Ideology: None & - & - & - \\
Left & & & $0.993 * * *(0.088)$ \\
Center & & & $0.717 * * *(0.098)$ \\
Right & & $0.572^{* * *}(0.074)$ & $0.688^{* * *}(0.090)$ \\
Access to Internet & & & $0.549 * * *(0.077)$ \\
Dummy CEP Jun2017 & & $-0.002(0.102)$ & $-0.075(0.104)$ \\
CEP August 2017 & $0.169(0.096)$ & $-0.321^{* * *}(0.106)$ & $-0.593 * * *(0.113)$ \\
CEP October 2017 & $-0.037(0.096)$ & $0.039(0.103)$ & $0.203 *(0.108)$ \\
CEP August 2018 & $0.137(0.097)$ & $0.212^{* *}(0.103)$ & $0.366^{* * *}(0.108)$ \\
CEP May 2019 & $0.409 * * *(0.100)$ & $0.758^{* * *}(0.096)$ & $1.043 * * *(0.105)$ \\
CEP December 2019 & $0.077(0.096)$ & $-3.396 * *(0.160)$ & $-3.709 * * *(0.170)$ \\
Constant & $-2.565^{* * *}(0.153)$ & 0.1540 & 0.1729 \\
R2 Nagelkerke & 0.2546 & 7315 & 7114 \\
N & 7315 & & \\
\hline
\end{tabular}

Source: authors with data from CEP polls \#79, \#80, \#81, \#82, \#83, and \#84, 2017-2019

$* * *$ Significant at $0.01 ; * *$ significant at $0.05 ; *$ significant at 0.10

access than the other two groups. Education also positively impacts access. Those who live in the Metropolitan Region also have more access. Since our prior expectation is that ideology does not determine access to the internet, we exclude ideological identification variables from Model 1 . Though these findings are not surprising, we underline that the biggest difference in access to the internet is between those in the highest SES group and the rest of the population. Thus, the material inequality is higher between the highest group and the other two groups.

In models 2 and 3, the dependent variable is the use of social networks to obtain political information. Younger people and those in higher SES groups are more likely to use social networks for this purpose. Those with less education, women, and those residing outside Santiago are less likely to do so. As expected, and given previous findings in the literature discussed above, those who identify on the ideological scale-with the left, center or right-are more likely to use the internet 
to obtain political information than the non-identified. Not surprisingly, those with access to the internet are more likely to use it to obtain political information.

Our first hypothesis postulates that people in higher SES groups are more likely to use online social networks to acquire political information. The results of the models are consistent with that expectation. However, as models 1, 2, and 3 show, SES differences are stronger in explaining access to the internet than the use of social networks to acquire political information. Also, the magnitude of the effect of a higher SES decreases in model 3, the model that includes ideological identification as an explanatory variable. Thus, while the data is consistent with the expectations of hypothesis 1 , the effect of SES in using social networks to acquire political information is less pronounced when we also take ideological identification into consideration. In fact, in Model 3, the magnitude of the effect of medium and high SES groups is similar-unlike in Model 2, where the magnitude of the highest socioeconomic group is substantially larger than that of the middle socio-economic group. The similar magnitudes imply that the difference in using social networks to acquire political information between the middle and highest group decreases when ideological identification is included in the models.

Hypothesis 2 postulates that age impacts the use of the internet to acquire political information. Younger people are more likely to have access to the internet (Model 1) and are also more likely to use social networks to acquire political information (Models 2 and 3). The impact of age is similar in affecting access to the internet and the use of social networks to acquire political information, both in the model that excludes ideological identification and in the model that includes it. The magnitude of the effect of education decreases somewhat in the model that includes identification on the ideological scale (Model 3). Yet, being younger remains a significant determinant of using social networks to acquire political information.

Hypothesis 3 asserts that those who identify on the ideological scale will be more likely to use social networks to acquire political information. As model 3 shows, those who identify anywhere on the ideological scale are more likely to use social networks to acquire political information than the non-identified. The effect of ideological identification on the left-right scale is particularly relevant, as Model 3 shows a decrease in the magnitude of the effect of SES when ideological identification is included in the model.

To graphically present our findings, Fig. 3 shows the marginal effects for the access to the internet by age and SES groups. While there are statistically significant differences between the lowest SES group and the rest, the mid and high SES groups report no statistically significant differences in access to the internet. Not surprisingly, access to the internet decreases with age, but interestingly, differences between socio-economic groups are lower among younger people than among the older age cohorts. While older people in higher socio-economic groups tend to have almost universal access to the internet, access to the internet increases rapidly for younger Chileans among those in mid and low socio-economic groups.

The image on the right in Fig. 3 shows the marginal effects for the use of social networks to acquire political information by age and socio-economic groups. There is a decline associated to age. Older people in all SES groups tend to make less use of social networks to acquire political information. However, the slopes for the 

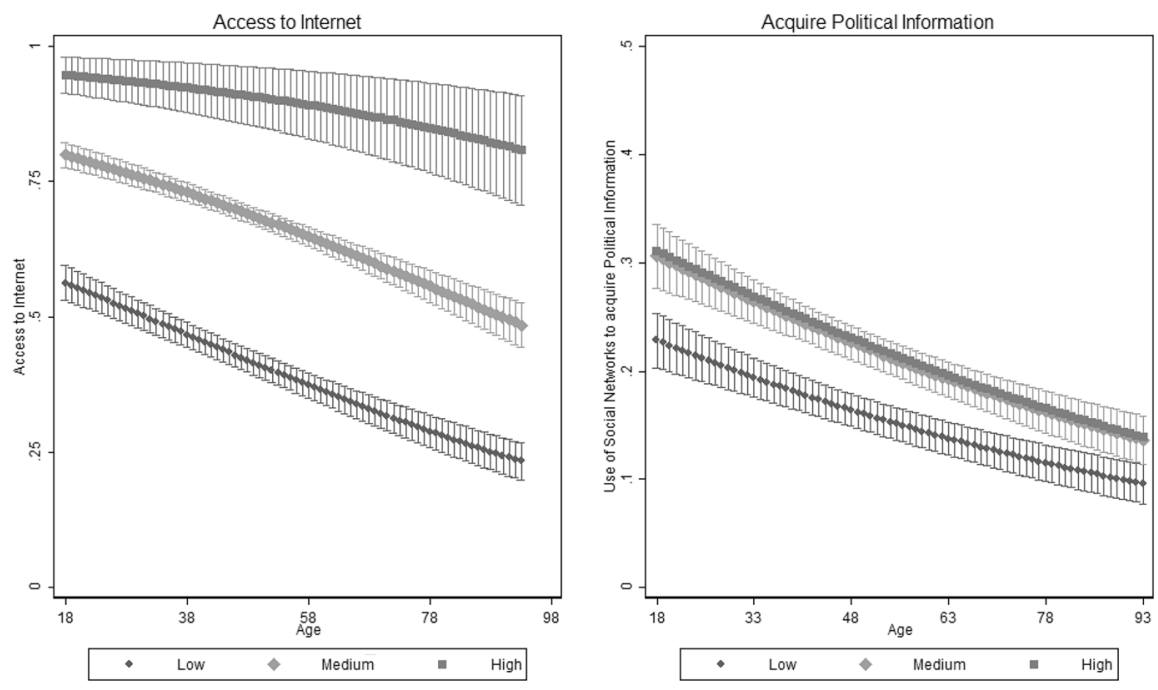

Fig. 3 Marginal effects for access to the internet and the use of social networks to acquire political information by age and socio-economic groups in Chile, 2017-2019. Source: authors with data from CEP polls \#79, \#80, \#81, \#82, \#83, and \#84, 2017-2019

highest and middle SES groups overlap. That indicates no discernable differences in the use of social networks to acquire political information among both groups. On the same line, the gap between the highest and lowest SES groups is far narrower than in the graph that depicts access to the internet. When it comes to acquiring political information on social networks, socio-economic differences are far less pronounced than in accessing the internet. This finding is consistent with what others have reported for the USA, where differences in preferences over distributional policies are more pronounced between the middle and lower-income groups than between the middle and upper-income groups (Enns \& Wlezien, 2011). As those in middle SES group are more similar to those in the high SES group, the distanceand perhaps even marginalization-of those in low SES groups becomes an even bigger challenge in the effort to promote democratic inclusion.

Figure 4 shows the marginal effects for the use of social networks to acquire political information by age and ideological identification. Those who do not identify on the ideological scale use social networks far less than the rest at all age groups, but they still use social networks to acquire political information more so than those who identify on the ideological scale in the older age cohorts. There are no differences between those who identify with the left, center, or right in their use of social networks to acquire political information. As generational replacement kicks in and the older cohorts are replaced by cohorts who are more inclined to use social networks to acquire political information, the intensity of democratic engagement might increase. After all, young people who declare not to identify with a position on the left-right ideological scale are still more likely to participate in democratic engagement online than older people who declare to have an ideological position. 


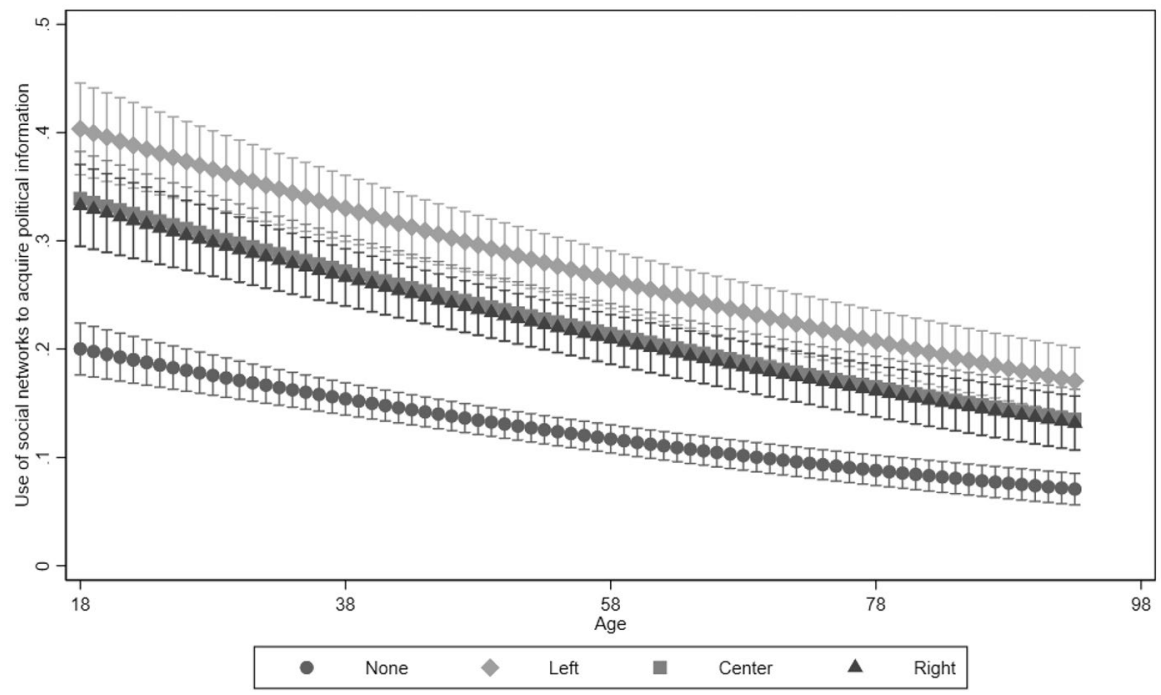

Fig. 4 Marginal effects on the use of social networks to acquire political information by age and ideological identification in Chile, 2017-2019. Source: Authors with CEP polls \#79, \#80, \#81, \#82, \#83, and \#84, 2017-2019

This finding underlines the importance of distinguishing between material and concrete inequalities, especially when it comes to different age groups. While material inequalities are undeniable among the upper and lower-income sectors in Chile, concrete inequalities, especially among the youth, are far more nuanced. The differences between the haves and have-nots in the use of social networks to acquire political information are far less pronounced among younger than among older Chileans.

Figure 5 shows the marginal effects for the use of social networks to acquire political information by age, years of education, sex, and place of residency. Since Chile has experienced a rapid expansion in access to education in the last 3 decades, we split the sample into those aged 40 or younger and older cohorts. Most people with very few years of education are among the older age cohorts. Not surprisingly, older people in all socio-economic groups use social networks to acquire political information less than younger people in their respective groups. But comparing between similar levels of education, those aged 40 or younger in the lowest SES group systematically use social networks more frequently to acquire political information than those aged 41 or older in the higher SES group. At similar number of years of education, younger people in low SES groups use social networks more than older people in higher SES groups. As the use of social networks is more widespread among younger people, this finding should not be very surprising. But the fact that younger people in low SES groups use social networks to acquire political information at the same rate-or even higher rate-than older people in the highest SES group points to a significant generational difference. While the socio-economic difference between top and middle-income groups and the lowest SES group prevails, the socio-economic gap is far less pronounced in the use of social networks to acquire 

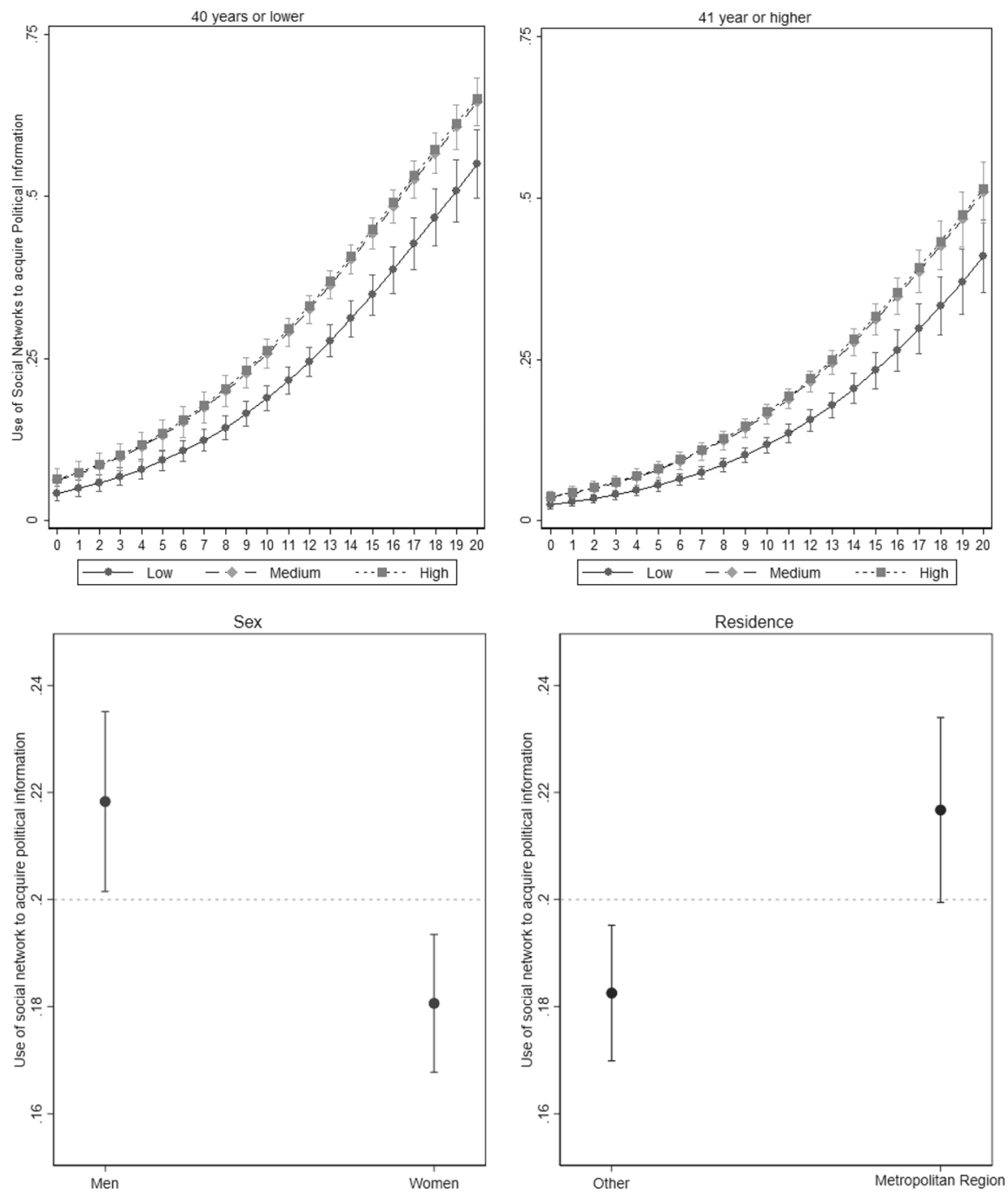

Fig. 5 Marginal effects in use of social networks to acquire political information by years of education, sex, and residency in Chile, 2017-2019. Source: Authors with CEP polls \#79, \#80, \#81, \#82, \#83, and \#84, 2017-2019

political information. The graphs on the bottom show that men used social networks to acquire political information more than women and that those who reside in the capital city of Santiago do it more than those who reside elsewhere in Chile.

Table 2 and Figs. 3, 4, and 5 report our findings on the effect of socio-demographic indicators on access to the internet and on the use of social networks to acquire political information. While the digital divide remains relevant-as access to the internet is associated to age and SES groups - the determinants of digital inequality in using social networks to acquire political information present a more nuanced picture. Age 
and SES groups have an impact, but the impact of age is far less pronounced among those in the high and middle SES groups. For all practical matters, those two groups behave very similarly in their use of social networks to acquire political information. Those in middle SES group are far more similar to those in the high SES group than to those in low SES group. Young people in middle and low SES groups tend to use the internet to acquire political information more than the older age cohort in the highest SES group.

Perhaps more importantly, young people who do not identify on the ideological scale tend to use the internet to acquire political information at similar levels than those in the older age cohorts who do identify on the left-right ideological scale. The non-ideologically identified youth use social networks to acquire political information at similar levels as people in older age cohorts who place themselves on the left-right ideological scale. The findings lend support to the claim that material inequality should be distinguished from concrete inequality. When we assess how people use social networks, concrete socio-economic status inequality is lower, especially among the youth.

One of the immediate implications of this finding has to do with how the sharp contrast between the more level playing field that exists in the use of social networks to acquire political information and the persistently high levels of inequality in other dimensions-including access to the internet. In countries where income and social inequality is high, the tensions associated to that inequality can potentially emerge in the more horizontal interactions that take place when people use social networks to acquire political information. These tensions can manifest themselves in both the dimension of what kind of political information people from different socio-economic status and ideological group access - which previous work has associated to the notion of echo chambers and the consumption of information that confirms prior beliefs and preferences - and in the type of interactions that take place between people of different socio-economic status and ideological preferences. In societies with high levels of income and social inequalities, the interactions between people with drastically different access to opportunities might turn into an ideological and social battleground where the consequences of inequality manifest themselves.

In the case of Chile, the social unrest that swept the country in late 2019 was widely attributed to discontent with the high levels of inequality (Somma et al, 2020). Our findings can help contribute to understand why the riots happened when they happened-and not before, when levels of inequality were even higher-as the way in which people acquire political information online points to decreasing differences in the behavior of younger people in the high and middle SES groups. When it comes to the use of social networks to acquire political information, those two groups are indistinguishable. Since levels of inequality have been historically high in Chile, the explanations for the social unrest of 2019 need to include a triggering effect-after all, the social unrest did not happen before, when levels of inequality were higher. We speculate that the reason for why the high levels of inequality have become more relevant in the public debate might be the level playing field among younger people from different socioeconomic status in the use of social networks to acquire political information. After all, when people are equal in one dimension-the use of social networks 
to acquire political information-inequalities in other dimensions might become more evident and salient. As we have shown, the fact that younger people who report no identification on the left-right scale and those who identify with the left, center, or right use social networks to acquire political information at the same levels points to higher levels of democratic engagement among the entirety of the younger population.

\section{Conclusion}

Using the case of Chile, a middle-income country with high levels of inequality that experienced rapid economic growth between 1990 and 2018, we have identified some novel patterns on the determinants of the use of social networks to acquire political information. While, not surprisingly, younger, more educated, and people in higher SES groups have more access to the internet and make more use of social networks to acquire political information, we have also found that the socioeconomic gap tends to significantly decrease among younger and more educated Chileans. In fact, the socio-economic differences in the use of social networks to acquire political information vanish when comparing younger age cohorts in the middle and high SES groups. Younger Chileans in the middle SES group use social networks to acquire political information at the same levels as younger Chileans in the high SES group and at higher levels than older Chileans in the high SES group. Moreover, young Chileans who do not identify ideologically tend to use social networks to acquire political information at similar levels as older Chileans who identify with the left, center or right on the ideological scale.

The implications of our findings are relevant beyond Chile. As other middleincome countries see the expansion in access to the internet and as industrialized countries experience worsening income inequality, the decreasing differences in the way in which high and middle SES groups make use of social networks to acquire political information might present challenges to the way democracy works. After all, when people experience equality - even if only in the dimension of using social networks to acquire political information-they might develop a preference for more equality in other dimensions of their lives-and can undertake political action to demand more equality.

In recent years, democratic engagement-including the access to political information-has increasingly taken place online. Moreover, with the lockdown orders triggered by the coronavirus pandemic starting in 2020, the digital divide and digital inequality gaps have become even more evident. As people cope with their governments' orders to stay indoors, in addition to differences in broadband access, the digital divide has been exacerbated by the fact that members of low socio-economic status households often share the same devices to access the internet and their living quarters do not easily lend themselves to work or study online. While the coronavirus crisis has aggravated the negative consequences of the digital divide and digital inequality in several dimensions, including democratic engagement and political participation, at the same time, as a response to the negative impact of the pandemic 
on traditional mechanisms of democratic participation-like in-person voting or massive street demonstrations_-online social networks emerge as an alternative vehicle for democratic engagement.

\section{References}

Ac1lar, A. (2011). Exploring the aspects of digital divide in a developing country. Issues in Informing Science and Information Technology, 8, 231-244.

AIM (Asociación Investigadores de Mercado y Opinión Publica de Chile). (2019). Clasificación grupos socioeconómicosy manual de aplicación. Santiago: AIM Chile. Accessed April 9, 2021, from https://www.aimchile.cl/wp-content/uploads/2020/07/Actualizaci\%C3\%B3n-y-Manual-GSEAIM-2019-1.pdf

Anduiza, E., Cantijoch, M., \& Gallego, A. (2009). Political participation and the Internet: A field essay. Information, Communication \& Society, 12(6), 860-878.

Anduiza, E., Cristancho, C., \& Sabucedo, J. M. (2014). Mobilization through online social networks: The political protest of the indignados in Spain. Information Communication \& Society, 17(6), 750-764.

Anduiza, E., Gallego, A., \& Cantijoch M. (2010). Online political participation in Spain: the impact of traditional and Internet resources. Journal of Information Technology \& Politics, 7(4), 356-368.

Antino, M., De Marco, S., Robles, J. M., \& Fernandez, E. G. (2016). Influence of abilities for searching commercial information online on e-shopping: When inequality affects business. Journal of Globalization, Competitiveness \& Governability/revista De Globalización, Competitividad y Gobernabilidad/revista De Globalização, Competitividade e Governabilidade, 10(3), 136-152.

Barberá, P., Jost, J. T., Nagler, J., Tucker, J. A., \& Bonneau, R. (2015). Tweeting from left to right: Is online political communication more than an echo chamber? Psychological Science, 26(10), $1531-1542$.

Baron, R.A., \& Byrne D. (1987). Social psychology: Understanding human interaction. Allyn \& Bacon.

Beyer, H., \& Le Foulon, C. (2002). Un recorrido por las desigualdades salariales en Chile. Estudios Públicos, 85, 139-175.

Boutyline, A., \& Willer, R. (2017). The social structure of political echo chambers: Variation in ideological homophily in online networks. Political Psychology, 38(3), 551-569.

Chen, W., \& Wellman, B. (2004). The global digital divide-within and between countries. IT \& Society, 1(7), 39-45.

Chen, W., \& Wellman, B. (2005). Charting digital divides: Comparing socioeconomic, gender, life stage, and rural-urban internet access and use in five countries. Cambridge, MA: MIT Press.

Chen, H. T., Chan, M., \& Lee, F. L. (2016). Social media use and democratic engagement: A comparative study of Hong Kong Taiwan and China. Chinese Journal of Communication, 9(4), 348-366.

Dalton, R. (2006). Citizen politics: Public opinion and political parties in advanced industrial democracies (4th ed.). Congressional Quartely Press.

DiMaggio, P., \& Hargittai, E. (2001). From the 'digital divide'to 'digital inequality': Studying Internet use as penetration increases. Princeton: Center for Arts and Cultural Policy Studies, Woodrow Wilson School, Princeton University, 4(1), 4-2.

Ekström, M., \& Östman, J. (2015). Information interaction and creative production: The effects of three forms of internet use on youth democratic engagement. Communication Research, 42(6), 796-818.

Enns, P. K., \& Wlezien, C. (2011). Group opinion and the study of representation. Who gets represented, $1-25$.

Fiske, S.T. (1993). Social cognition and social perception. Annual review of psychology, 44(1), 155-194.

Fuchs, C. (2009). The role of income inequality in a multivariate cross-national analysis of the digital divide. Social Science Computer Review, 27(1), 41-58.

Fuch, C., \& Horak, E. (2008). Africa and the digital divide. Telematics and informatics, 25, 99-116. https://doi.org/10.1016/j.tele.2006.06.004

Gil de Zúñiga, H., Jung, N., \& Valenzuela, S. (2012). Social media use for news and individuals' social capital, civic engagement and political participation. Journal of Computer-Mediated Communication, 17(3), 319-336. 
Glynn, C. J., Huge, M. E., \& Hoffman, L. H. (2012). All the news that's fit to post: A profile of news use on social networking sites. Computers in Human Behavior, 28(1), 113-119.

Grönlund, K. (2007). Knowing and not knowing: The internet and political information. Scandinavian Political Studies, 30(3), 397-418.

Hargittai, E., \& Hinnant, A. (2008). Digital inequality: Differences in young adults' use of the Internet. Communication Research, 35(5), 602-621.

Ho, C. C., \& Tseng, S. F. (2006). From digital divide to digital inequality: The global perspective. International Journal of Internet and Enterprise Management, 4(3), 215-227.

Holt, K., Shehata, A., Strömbäck, J., \& Ljungberg, E. (2013). Age and the effects of news media attention and social media use on political interest and participation: Do social media function as leveller? European Journal of Communication, 28(1), 19-34.

Hsieh, J. P. A., Rai, A., \& Keil, M. (2008). Understanding digital inequality: Comparing continued use behavioral models of the socio-economically advantaged and disadvantaged. MIS quarterly, 97-126.

Hughes, S., \& Mellado, C. (2016). Protest and accountability without the press: The press, politicians, and civil society in Chile. The International Journal of Press/politics, 21(1), 48-67.

Jouet, J., Vedel, T., \& Comby, J. B. (2011). Political information and interpersonal conversations in a multimedia environment: A quantitative and qualitative examination of information practices in France. European Journal of Communication, 26(4), 361-375.

Kaye, B. K., \& Johnson, T. J. (2002). Online and in the know: Uses and gratifications of the web for political information. Journal of Broadcasting \& Electronic Media, 46(1), 54-71.

Kaye, B. K., \& Johnson, T. J. (2004). A Web for all reasons: Uses and gratifications of Internet components for political information. Telematics and Informatics, 21(3), 197-223.

Kubey, R. W., Lavin, M. J., \& Barrows, J. R. (2001). Internet use and collegiate academic performance decrements: Early findings. Journal of Communication, 51(2), 366-382.

Larrañaga, O., \& Rodríguez, M.E. (2014). Desigualdad de Ingresos y Pobreza en Chile 1990 a 2013. Working Papers Programa de las Naciones Unidas para el Desarrollo (PNUD). https://www.undp. org/content/dam/chile/docs/pobreza/undp_cl_pobreza_cap_7_desigu-y-pob_editada.pdf

Leyva, R. (2017). Exploring UK millennials' social media consumption patterns and participation in elections, activism, and “slacktivism." Social Science Computer Review, 35(4), 462-479. https://doi. org/10.1177/0894439316655738

Maldifassi, J. O., \& Canessa, E. C. (2009). Information technology in Chile: How perceptions and use are related to age, gender, and social class. Technology in Society, 31(3), 273-286.

Min, S. J. (2010). From the digital divide to the democratic divide: Internet skills, political interest, and the second-level digital divide in political internet use. Journal of Information Technology \& Politics, 7(1), 22-35.

Morris, D. S., \& Morris, J. S. (2013). Digital inequality and participation in the political process: Real or imagined? Social Science Computer Review, 31(5), 589-600.

Navia, P., \& Perello, L. (2019). One-night stands and long-term commitments: Presidential app roval for Sebastián Piñera in chile, 2009-2014. Revista De Ciencia Politica, 39(1), 49-73.

Norris, P. (2000). A virtuous circle: Political communications in postindustrial societies. Cambridge University Press.

Ono, H., \& Zavodny, M. (2007). Digital inequality: A five country comparison using microdata. Social Science Research, 36(3), 1135-1155.

PNUD (Programa de Naciones Unidas para el Desarrollo). (2017a). Chile en 20 años: Un recorrido a través de los informes sobre Desarrollo Humano. Santiago.

PNUD (Programa de Naciones Unidas para el Desarrollo). (2017b). Desiguales: Orígenes cambios y desafios de la brecha social en Chile. Santiago.

Quijada, C. C. (2014). Estudiantes conectados y movilizados: El uso de Facebook en las protestas estudiantiles en Chile. Comunicar: Revista científica iberoamericana de comunicación y educación, (43), 25-33.

Quiroga, M. M. (2008). La primera mujer presidenta de Chile:¿ Qué explicó el triunfo de Michelle Bachelet en las elecciones de 2005-2006?. Latin American Research Review, 43(1).

Ramírez-Correa, P., Painén-Aravena, G., Alfaro-Peréz, J., Mariano, A. M., \& Machorro-Ramos, F. (2019). Motivaciones hedónicas para el uso de sitios de redes sociales por adultos mayores: Un estudio exploratorio en Chile. Revista Ibérica De Sistemas e Tecnologias De Informação, E17, 563-570.

Ruiz-Tagle, J. A. (1999). Chile: 40 años de desigualdad de ingresos (No. 165). Universidad de Chile, Facultad de Ciencias Económicas y Administrativas, Departamento de Economía. 
Scherman, A., Arriagada, A., \& Valenzuela, S. (2013). La protesta en la era de las redes sociales: El caso chileno. Intermedios. Medios De Comunicación y Democracia En Chile, 1, 179-197.

Somma, N.M., Bargsted, M., Disi Pavlic, R., \& Medel, R. M. (2020). No water in theoasis: the Chilean Spring of 2019-2020. Social Movement Studies,1-8.

Stangor, C., \& McMillan D. (1992). Memory for expectancy-congruent and expectancy-incongruent information: A review of the social and social developmental literatures. Psychological Bulletin, 111(1): 42 .

Stoycheff, E., Nisbet, E. C., \& Epstein, D. (2020). Differential effects of capital-enhancing and recreational Internet use on citizens' demand for democracy. Communication Research, 47(7), 1034-1055.

Taneja, H., \& Viswanathan, V. (2014). Still glued to the box? Television viewing explained in a multiplatform age integrating individual and situational predictors. International Journal of Communication, 8(26), 2134-2159.

Taneja, H., Wu, A. X., \& Edgerly, S. (2018). Rethinking the generational gap in online news use: An infrastructural perspective. New Media \& Society, 20(5), 1792-1812.

Tewksbury, D., Weaver, A. J., \& Maddex, B. D. (2001). Accidentally informed: Incidental news exposure on the World Wide Web. Journalism \& Mass Communication Quarterly, 78(3), 533-554.

Tilly, C. (2001). Relational Origins of Inequality. Anthropological Theory, 1(3), 355-372.

Valenzuela, J. S., Scully, T. R., \& Somma, N. (2007). The enduring presence of religion in Chilean ideological positionings and voter options. Comparative Politics, 40(1), 1-20.

Valenzuela, S., \& Arriagada, A. (2011). Politics without citizens Public opinion television news the president and real-world factors in Chile 2000-2005. The International Journal of Press/politics, 16(3), 357-381.

Van Deursen, A. J., Helsper, E., Eynon, R., \& Van Dijk, J. A. (2017). The compoundness and sequentiality of digital inequality. International Journal of Communication, 11, 452-473.

Wang, S. I. (2007). Political use of the Internet, political attitudes and political participation. Asian Journal of Communication, 17(4), 381-395.

Weaver Lariscy, R., Tinkham, S. F., \& Sweetser, K. D. (2011). Kids these days: Examining differences in political uses and gratifications, Internet political participation, political information efficacy, and cynicism on the basis of age. American Behavioral Scientist, 55(6), 749-764.

Xenos, M., \& Moy, P. (2007). Direct and differential effects of the Internet on political and civic engagement. Journal of Communication, 57(4), 704-718.

Yamamoto, M., Kushin, M. J., \& Dalisay, F. (2015). Social media and mobiles as political mobilization forces for young adults: Examining the moderating role of online political expression in political participation. New Media \& Society, 17(6), 880-898.

Publisher's Note Springer Nature remains neutral with regard to jurisdictional claims in published maps and institutional affiliations. 